\title{
DNA-DNA hybridization determined in micro-wells using covalent attachment of DNA
}

\author{
Henrik Christensen, ${ }^{1}$ Øystein Angen, ${ }^{2}$ Reinier Mutters, ${ }^{3}$ \\ John E. Olsen ${ }^{1}$ and Magne Bisgaard ${ }^{1}$
}

Author for correspondence: Henrik Christensen. Tel: +45 35282783. Fax: +4535282757.

e-mail: hech@kvl.dk

1 Department of Veterinary Microbiology, The Royal Veterinary and Agricultural University, Stigbøjlen 4, DK-1870 Frederiksberg C, Denmark

2 Danish Veterinary Laboratory, Bülowsvej 27, DK-1790 Copenhagen V, Denmark

3 Institute of Medical Microbiology and Hospital Hygiene, Philipps University, Pilgrimstein 2, D-35037 Marburg, Germany
The present study was aimed at reducing the time and labour used to perform DNA-DNA hybridizations for classification of bacteria at the species level. A micro-well-format DNA hybridization method was developed and validated. DNA extractions were performed by a small-scale method and DNA was sheared mechanically into fragments of between 400 and 700 bases. The hybridization conditions were calibrated according to DNA similarities obtained by the spectrophotometric method using strains within the family Pasteurellaceae. Optimal conditions were obtained with 300 ng DNA added per well and bound by covalent attachment to NucleoLink. Hybridization was performed with $500 \mathrm{ng}$ DNA, $5 \%$ (w/w) of which was labelled with photoactivatable biotin (competitive hybridization) for $2.5 \mathrm{~h}$ at $65^{\circ} \mathrm{C}$ in $2 \times \mathrm{SSC}$ followed by stringent washing with $2 \times$ SSC at the same temperature. The criteria for acceptance of results were a maximum of $15 \%$ standard deviation, calculated as a percentage of the mean for four replicate micro-wells, and that DNA similarities were not significantly different in at least two independent experiments. The relationship between DNA similarities obtained by the microwell method $(y)$ and by the spectrophotometric method $(x)$ was $y=$ $0.534 x+30.6$, when these criteria had been applied to 23 pairs of strains of Actinobacillus species, avian [Pasteurella] haemolytica-like bacteria and Mannheimia species. The correlation (Pearson) between DNA similarities obtained by interchange of strains used for covalent binding and hybridization was 0.794 . Significantly lower DNA similarities were observed by the spectrophotometric compared with the micro-well method for three pairs of hybridizations. After removal of these data, the relationship between DNA similarities obtained by the micro-well and spectrophotometric methods improved to $y=0.855 x+11.0$. It was found that the accuracy and precision of the micro-well method was at the same level as that of the spectrophotometric method, but the labour and analysis time were reduced significantly. The use of hybridization in the micro-well format will allow DNA-DNA hybridizations to be carried out between all strains selected for a particular taxonomic study, in order to construct complete data matrices and improve species definition.

Keywords: DNA-DNA hybridization, Pasteurellaceae, micro-well, taxonomy

\section{INTRODUCTION}

Hybridizations between total genomic DNA preparations are fundamental for classification of bacteria at

Abbreviations: EDC, 1-ethyl-3-(3-dimethylaminopropyl)-carbodiimide; 1-Melm, 1-methylimidazole buffer; PAB, photo-activatable biotin. the species level (Murray et al., 1990; Vandamme et al., 1996; Wayne et al., 1987). The existing spectrophotometric, filter competition, S1 nuclease and hydroxyapatite methods are reliable (De Ley et al., 1970; Grimont et al., 1980; Johnson, 1984) but timeconsuming, due to the large amount and high purity of DNA required. Another problem is that these methods 
are not easy to automate. The present lack of methodological improvement limits the resolution of complex bacterial groups at the species level. One example is the family Pasteurellaceae, within which numerous unclassified taxa exist (Christensen \& Bisgaard, 1997). The need for rapid, miniaturized, automated and standardized methods for DNA-DNA hybridization was pointed out by Vandamme et al. (1996).

A micro format DNA-DNA hybridization protocol was described by Ezaki et al. (1988, 1989), in which DNA was fixed to the surface of micro-wells by physical adsorption. However, the low retention efficiency results in a requirement for large amounts of DNA and the immobilized DNA is probably relatively inaccessible because only a small part of the target is available for hybridization. The method was improved by covalent attachment of DNA to CovaLink microwell plates (Rasmussen et al., 1991) for detection of streptococci and aeromonads (Adnan et al., 1993; Kaznowski, 1995).

In the present study, covalent attachment of DNA to NucleoLink micro-well strips (Nalge Nunc International) was used to develop a micro-well DNADNA hybridization assay. NucleoLink strips were selected for the present study because the binding efficiency of DNA to NucleoLink has been shown to be five to 10 times higher than to CovaLink (Oroskar et al., 1996). NucleoLink strips are made of an activated heat-stable polymer and support covalent binding of DNA by carbodiimide-mediated condensation, and these strips can be assembled in micro-well format and used in micro-well plate readers (Chu et al., 1983; Ghosh \& Musso, 1987; Oroskar et al., 1996; Rasmussen et al., 1991; Wolf et al., 1987).

The new method was validated with strains of the Pasteurellaceae for which DNA similarities have been determined by the spectrophotometric method.

\section{METHODS}

DNA extraction. Initial DNA-attachment studies of covalent binding to micro-well strips were performed with DNA (Sigma) that had been isolated from Escherichia coli by the procedure of Marmur (1961).

For validation of the method against DNA similarities determined by the spectrophotometric method, strains of Actinobacillus equuli, avian [Pasteurella] haemolytica-like bacteria, 'Actinobacillus salpingitidis', Mannheimia species and strains of the provisional taxon 11 (Table 1) were cultured in $40 \mathrm{ml}$ brain/heart infusion broth (Difco) for $18 \mathrm{~h}$. Cells were harvested by centrifugation for $10 \mathrm{~min}$ at $5900 \mathrm{~g}$. The pellet was washed in 10 ml 50:10 TE buffer (50 mM Tris $/ \mathrm{HCl}, 10 \mathrm{mM}$ EDTA, pH 8), concentrated by centrifugation and resuspended in $10 \mathrm{ml} \mathrm{50:10} \mathrm{TE} \mathrm{buffer.}$ Lysozyme $(10 \mathrm{mg})$ was dissolved in the cell solution and allowed to act at $37^{\circ} \mathrm{C}$ for $30 \mathrm{~min}$. Next, $1 \mathrm{ml}$ of $10 \mathrm{mg}$ proteinase $\mathrm{K} \mathrm{ml}^{-1}$ was added to each tube and the tubes were turned 10 times before they were incubated at $56{ }^{\circ} \mathrm{C}$ for $2 \mathrm{~h}$. For precipitation of protein and cell debris, $6 \mathrm{ml} 1.5 \mathrm{M}$ potassium acetate was added, the tubes were turned 50 times and centrifuged for $15 \mathrm{~min}$ at $12100 \mathrm{~g}$. The supernatant was collected through sterile gauze and mixed with $10 \mathrm{ml} 2$ propanol by turning the tube 10 times. After $10 \mathrm{~min}$ rest, centrifugation was performed at $12100 \mathrm{~g}$ for $15 \mathrm{~min}$. The supernatant was decanted and the pellet was washed with $70 \%(\mathrm{v} / \mathrm{v})$ ice-cold ethanol by centrifugation at $12100 \mathrm{~g}$ for $10 \mathrm{~min}$ and the pellet was dried. The pellet was subsequently redissolved in $5 \mathrm{ml} \mathrm{10:1} \mathrm{TE} \mathrm{buffer}(10 \mathrm{mM}$ Tris $/ \mathrm{HCl}, 1 \mathrm{mM}$ EDTA, pH 8) and $25 \mu \mathrm{l}$ of a solution of $10 \mathrm{mg}$ DNase-free RNase $\mathrm{ml}^{-1}$ was added, with subsequent incubation at $37^{\circ} \mathrm{C}$ for $30 \mathrm{~min}$. Five $\mathrm{ml}$ phenol:chloroform:isoamyl alcohol $(25: 24: 1)$ was added and the solution was turned until it was milky-white. The solution was centrifuged at $5900 \mathrm{~g}$ for $15 \mathrm{~min}$ and $4 \mathrm{ml}$ of the upper phase was transferred to a new tube. One vol. chloroform:isoamyl alcohol (24:1) was added, the tube was turned until the content was mixed and centrifugation was carried out at $5900 \mathrm{~g}$ for $15 \mathrm{~min}$. The upper phase was transferred to a new tube and DNA was precipitated with $0 \cdot 1$ vols $3 \mathrm{M}$ sodium acetate $(\mathrm{pH} 5 \cdot 2)$ and 2 vols $96 \%$ (v/v) ethanol. The solution was left for $30 \mathrm{~min}$ at $-20{ }^{\circ} \mathrm{C}$ and centrifuged at $12100 \mathrm{~g}$ for $30 \mathrm{~min}$. The supernatant was decanted and the pellet was washed in $70 \%(\mathrm{v} / \mathrm{v})$ ice-cold ethanol by centrifugation. The pellet was dried and resuspended in $5 \mathrm{ml}$ distilled, filter-sterilized water (MilliQ). DNA was sheared twice in a French pressure cell at $2.3 \times 10^{8}$ $\mathrm{Pa}$ (15000 p.s.i.) to fragments of between 400 and $700 \mathrm{bp}$, as confirmed by agarose gel electrophoresis. As an alternative to the French pressure cell, DNA was sheared by passing samples twice through a cell disrupter operated at $2.3 \times 10^{8}$ $\mathrm{Pa}$ (Cell Disruption Systems, Constant Systems). If traces of RNA were observed by agarose gel electrophoresis of the DNA preparation, the RNase treatment was repeated, including extractions and precipitations. To remove any flocculent material, DNA was sterile-filtered $(0.20 \mu \mathrm{m}$, Minisart; Sartorius). To enable filtration, DNA was denatured $\left(100^{\circ} \mathrm{C}, 10 \mathrm{~min}\right)$ and immediately put on crushed ice before the filtration.

Binding of DNA to micro-wells. The first step in the covalent binding process is to generate a phosphorimidazolide by reacting the 5 -phosphoryl groups of nucleic acid with 1ethyl-3-(3-dimethylaminopropyl)-carbodiimide (EDC) in 1methylimidazole buffer (1-MeIm) (Ghosh \& Musso, 1987). The EDC-activated DNA is unstable and reacts with 1MeIm. The 1-MeIm-activated DNA then binds covalently to the NucleoLink surface. Optimal binding was achieved with $300 \mathrm{ng}$ DNA (stock solution 50-150 $\mathrm{ng} \mu \mathrm{l}^{-1}$ ) diluted in ice-cold $10 \mathrm{mM}$ 1-MeIm (Sigma), $\mathrm{pH} 7$, distributed with $75 \mu \mathrm{l}$ in each well. Twenty-five $\mu 140 \mathrm{mM}$ EDC (Sigma) dissolved in $10 \mathrm{mM}$ 1-MeIm was added and the sealed strips (heat-resistant sealing tape; Nalge Nunc International) were incubated at $50{ }^{\circ} \mathrm{C}$ for $18 \mathrm{~h}$ without shaking. To remove unattached DNA and make the attached DNA singlestranded, wells were washed three times with $0.4 \mathrm{M} \mathrm{NaOH}$ plus $0.25 \%(\mathrm{v} / \mathrm{v}) \mathrm{Tween} 20$ at $50{ }^{\circ} \mathrm{C}$. After $15 \mathrm{~min}$ at $50{ }^{\circ} \mathrm{C}$ with the $\mathrm{NaOH}$ solution, the $\mathrm{NaOH}$ wash was repeated. Wells were then rinsed three times with MilliQ water, rested for 5 min with water and then rinsed three more times. Wells were washed three times with $0 \cdot 2 \mathrm{M} \mathrm{NaOH}$ and $0 \cdot 1 \%(\mathrm{v} / \mathrm{v})$ Tween 20 at ambient temperature, rested with the $\mathrm{NaOH}$ solution for $5 \mathrm{~min}$ and then washed three more times with the $\mathrm{NaOH}$ solution. Finally, wells were washed three times with $100 \mathrm{mM}$ Tris/ $\mathrm{HCl}, \mathrm{pH} 7 \cdot 5,150 \mathrm{mM} \mathrm{NaCl}$ and $0 \cdot 1 \%$ (v/v) Tween 20 at ambient temperature, rested for 5 min with the solution and then washed three more times. Strips coated with DNA were stored at $4{ }^{\circ} \mathrm{C}$ in sealed plastic bags for a maximum of $5 \mathrm{~d}$ before hybridization. 
Table 1. Bacterial strains used for development of the micro-well method

DNA of the strains listed was used for development of the micro-well method by covalent attachment of DNA to determine DNA similarity and for comparison of DNA similarities with the spectrophotometric method. DNA G $+\mathrm{C}$ contents are indicated. References are given to reports of DNA similarities determined by the spectrophotometric method. ND, Not determined.

\begin{tabular}{|c|c|c|c|}
\hline Taxon & Strain & $\begin{array}{c}G+C \text { content } \\
(\mathrm{mol} \%)\end{array}$ & Reference \\
\hline Actinobacillus equuli & NCTC $8529^{\mathrm{T}}$ & $42 \cdot 9$ & Bisgaard et al. (1984) \\
\hline Taxon 11 & F 154 & $42 \cdot 2$ & Bisgaard et al. (1984) \\
\hline \multirow{4}{*}{ 'Actinobacillus salpingitidis' } & CCM 5974 & $40 \cdot 3$ & Piechulla et al. (1985) \\
\hline & CCM 5975 & $41 \cdot 3$ & Piechulla et al. (1985) \\
\hline & CCM 5976 & $40 \cdot 4$ & Piechulla et al. (1985) \\
\hline & CCM 5995 & $42 \cdot 1$ & Piechulla et al. (1985) \\
\hline \multirow[t]{2}{*}{ Mannheimia haemolytica } & NCTC $9380^{\mathrm{T}}$ & $43 \cdot 6$ & Angen et al. (1999) \\
\hline & 265 & $\mathrm{ND}$ & Angen et al. (1999) \\
\hline \multirow[t]{5}{*}{ Mannheimia glucosida } & $\mathrm{P} 925^{\mathrm{T}}$ & $41 \cdot 6$ & Angen et al. (1999) \\
\hline & P 731 & $43 \cdot 2$ & Angen et al. (1999) \\
\hline & UT 18 & $41 \cdot 8$ & Angen et al. (1999) \\
\hline & P 737 & $43 \cdot 5$ & Angen et al. (1999) \\
\hline & P 730 & $43 \cdot 9$ & Angen et al. (1999) \\
\hline \multirow[t]{3}{*}{ Mannheimia spp. } & UT 27 & $43 \cdot 7$ & Angen et al. (1999) \\
\hline & R 19.2 & ND & Angen et al. (1999) \\
\hline & HPA 121 & $40 \cdot 2$ & Angen et al. (1999) \\
\hline \multirow[t]{2}{*}{ [Pasteurella] haemolytica-like } & F 114 & $40 \cdot 9$ & Piechulla et al. (1985) \\
\hline & Gerl. 3348 & $42 \cdot 6$ & Piechulla et al. (1985) \\
\hline
\end{tabular}

DNA labelling with photo-activatable biotin (PAB). For detection of the degree of DNA-DNA hybridization, DNA was labelled by PAB, which forms a stable aryl nitrene that binds covalently to the aromatic bases of nucleic acids (Ezaki et al., 1988; Forster et al., 1985). Biotin is bound via a spacer arm of poly $(\mathrm{U})_{11}$ and one biotin has been estimated to be incorporated per 100-400 bases (Forster et al., 1985). DNA was labelled by PAB (EZ-Link; Pierce) according to the manufacturer's protocol and the protocols of Forster et al. (1985) and Clontech. Ten $\mu 1 \mathrm{PAB}$ dissolved in water to $1 \mu \mathrm{g} \mu \mathrm{l}^{-1}$ and DNA at a concentration of $0 \cdot 5-1 \cdot 0 \mu \mathrm{g} \mu \mathrm{l}^{-1}$ in 10-30 $\mu$ MilliQ water were mixed under subdued light in micro tubes $(1.5 \mathrm{ml})$. The tubes were illuminated with their lids open, $10 \mathrm{~cm}$ below a $400 \mathrm{~W}$ Philips sun-lamp (SGR 140) for $30 \mathrm{~min}$ on crushed ice. TE buffer $(100 \mathrm{mM}$ Tris $/ \mathrm{HCl}$, $1 \mathrm{mM}$ EDTA, pH 9) was added to the solution to $100 \mu \mathrm{l}$ and the solution was extracted twice with $100 \mu \mathrm{l} 2$-butanol. The volume was returned to $100 \mu \mathrm{l}$ with water and DNA was precipitated with $50 \mu 17 \cdot 5 \mathrm{M}$ ammonium acetate and $300 \mu \mathrm{l}$ ice-cold ethanol for $1 \mathrm{~h}$ at $-20^{\circ} \mathrm{C}$. DNA was pelleted $(15000 \mathrm{~g}, 15 \mathrm{~min})$ and the pellet was washed once with icecold $70 \%(\mathrm{v} / \mathrm{v})$ ethanol, dried in a speed-vac and redissolved in $20 \mu \mathrm{l}$ MilliQ water. The DNA concentration was determined fluorometrically with Hoechst 33258 (Paul \& Myers, 1982). Quantification of DNA with Picogreen (Molecular Probes) corresponded to the results obtained by the Hoechst 33258 method. The mean recovery of DNA through the PAB-labelling procedure was $62 \%$ (four independent experiments).

Hybridization with PAB-labelled DNA to DNA attached to micro-wells. PAB-labelled DNA was diluted 1:20 with unlabelled DNA to achieve competitive hybridization. During competitive hybridization, unlabelled DNA fragments compete with labelled DNA for duplex formation to DNA bound to the well surface (Johnson, 1981). The mixture of PAB-labelled and unlabelled DNA solutions was heated at $100{ }^{\circ} \mathrm{C}$ for $10 \mathrm{~min}$ and held at $65^{\circ} \mathrm{C}$. The formula $T_{\mathrm{m}}=$ $81 \cdot 5+16 \cdot 6 \log (M)+0 \cdot 41\left(\mathrm{G}+\mathrm{C}\right.$ mol \%) (Schildkraut ${ }^{\mathrm{m}}$ \& Lifson, 1965) was used to calculate the hybridization temperature. By insertion of the molarity of monovalent cations, $M=0 \cdot 39$, in $2 \times \mathrm{SSC}$ and the molar $\mathrm{G}+\mathrm{C}$ content of $42 \mathrm{~mol} \%$ (Table 1 ), the $T_{\mathrm{m}}$ was calculated to be $95^{\circ} \mathrm{C}$. The maximum rate of hybridization is obtained $16-32^{\circ} \mathrm{C}$ below the $T_{\mathrm{m}}$ (Wetmur \& Davidson, 1968) and a hybridization temperature of $65^{\circ} \mathrm{C}$ was selected, $30^{\circ} \mathrm{C}$ below the $T_{\mathrm{m}}$.

Hybridization was carried out for $2.5 \mathrm{~h}$ with $500 \mathrm{ng}$ PABlabelled DNA solution per well in $100 \mu \mathrm{l} 2 \times \mathrm{SSC}, 0 \cdot 1 \%$ $(\mathrm{v} / \mathrm{v})$ Tween 20 and $0.5 \%(\mathrm{v} / \mathrm{v})$ blocking reagent (cat. no. 1096176; Boehringer Mannheim). Wells were sealed with heat-resistant sealing tape (Nalge Nunc International) and the strips were mounted with gel-clamps between silicone plates and glass plates to hinder evaporation during hybridization. Shaking was not applied during hybridization. Washing was performed three times with $2 \times \mathrm{SSC}$ containing $0 \cdot 1 \%(\mathrm{v} / \mathrm{v})$ Tween 20 at ambient temperature and then wells were heated to $65^{\circ} \mathrm{C}$ with the solution and held at that temperature for $15 \mathrm{~min}$ without shaking. Washing was then performed three more times with $2 \times$ SSC containing $0 \cdot 1 \%(\mathrm{v} / \mathrm{v})$ Tween 20 at ambient temperature.

Detection of DNA hybridization. The amount of biotinlabelled DNA bound to wells after stringent washing was determined by the addition of streptavidin-conjugated alkaline phosphatase acting on the substrate 4-methylumbelli- 
feryl phosphate (4-MUP), which generates a fluorescent signal (Nalge Nunc International).

The detection system recommended for a specific PCR test run in NucleoLink strips was utilized (Nalge Nunc International). Aliquots of $100 \mu \mathrm{l}$ streptavidin-conjugated alkaline phosphatase (Dako) diluted 1:3000 in $100 \mathrm{mM}$ Tris $/ \mathrm{HCl}, \mathrm{pH} 7 \cdot 5,150 \mathrm{mM} \mathrm{NaCl}, 0 \cdot 1 \%$ (v/v) Tween 20 and $0.5 \%(\mathrm{v} / \mathrm{v})$ blocking reagent (Boehringer Mannheim) were added to the wells. The wells were sealed and incubated for $1 \mathrm{~h}$ at $37^{\circ} \mathrm{C}$ and then washed three times with $100 \mathrm{mM}$ Tris $/ \mathrm{HCl}, \mathrm{pH} 7 \cdot 5,150 \mathrm{mM} \mathrm{NaCl}$ and $0 \cdot 1 \%(\mathrm{v} / \mathrm{v})$ Tween 20 at ambient temperature. The wells were rested for 5 min and the washing was repeated three more times. For fluorometric detection, $100 \mu 11 \mathrm{mM}$ 4-MUP (Sigma) in $1 \mathrm{M}$ diethanolamine, $\mathrm{pH} 9 \cdot 8$, and $1 \mathrm{mM} \mathrm{MgCl}{ }_{2}$ was added. The wells were sealed and incubated at $37^{\circ} \mathrm{C}$ for $1 \mathrm{~h}$ in the dark. The reaction was stopped by the addition of $50 \mu 13 \mathrm{M} \mathrm{K}_{2} \mathrm{HPO}_{4}$ and fluorescence was read in an LS-50B fluorometer (Perkin Elmer) at $350 \mathrm{~nm}$ excitation and $480 \mathrm{~nm}$ emission, with a slit width of 3 and $3 \mathrm{~s}$ reading time. The relationship between signal and reaction time was found to be linear up to $2 \mathrm{~h}$. Background hybridization was determined in wells without covalently bound DNA. The background hybridization, expressed as the percentage of homologous hybridization (the reference strain with itself), was around $10 \%$ for a $2.5 \mathrm{~h}$ hybridization period. The degree of background hybridization was determined in each experiment.

Quantification. The percentage DNA similarity was calculated as $100\left[\left(I_{\text {test }}-I_{\text {blank }}\right) /\left(I_{\text {ref }}-I_{\text {blank }}\right)\right]$, where $I_{\text {test }}$ is the intensity of hybridization between the strain to be tested and the reference strain, $I_{\text {ref }}$ is the intensity of hybridization of the reference strain with itself and $I_{\text {blank }}$ is the background hybridization. Each experiment was performed with four replicates. The differences of mean DNA similarities between experiments were evaluated statistically by the d-test (Campbell, 1981).

\section{RESULTS AND DISCUSSION}

\section{Binding of sheared DNA to micro-wells}

The optimal level of DNA required for covalent binding was determined by homologous hybridization. From Fig. 1, the hybridization signal is seen to increase linearly with the concentration of unlabelled DNA added up to $200 \mathrm{ng}$ per well. By application of higher DNA concentrations, the signals were gradually reduced, probably because of prevention of DNA binding to the surface. For the micro-well hybridization method, $300 \mathrm{ng}$ DNA per well was chosen for binding to secure an even level of DNA in all wells. DNA of $E$. coli performed similarly to that from Mannheimia haemolytica, which showed that the binding is applicable to different bacterial groups and to DNA extracted by different protocols. The binding of DNA to the NucleoLink polymer surface was developed originally with 5'-phosphorylated oligonucleotides (Oroskar et al., 1996). Our results show further that binding of mechanically sheared DNA to the NucleoLink surface is possible.

\section{Adjustment of the hybridization conditions}

The time of hybridization and the strength of SSC in the hybridization buffer were adjusted at a constant

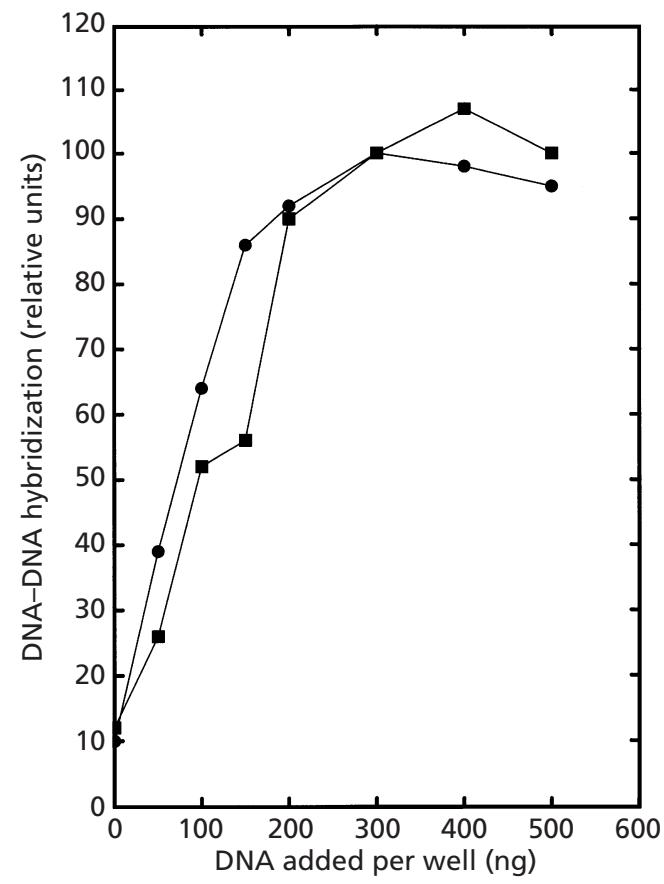

Fig. 1. Relationship between degree of DNA-DNA hybridization and amount of DNA bound to NucleoLink wells for DNA of $M$. haemolytica strain NCTC $9380^{\top}(\boldsymbol{\square})$ and $E$. coli strain B (•) in homologous hybridization. The DNA-DNA hybridization achieved at $300 \mathrm{ng}$ bound DNA was set to 100 and the other values were normalized to this level. Data points represent single measurements.

hybridization temperature of $65^{\circ} \mathrm{C}$ to obtain correspondence to the DNA similarity obtained by the spectrophotometric method.

A hybridization time of $2.5 \mathrm{~h}$ was chosen for the method because of the greater precision observed [the coefficient of variation (SD as a percentage of the mean) decreased from $13 \%$ at $18 \mathrm{~h}$ to $10 \%$ at $2 \cdot 5 \mathrm{~h}$ hybridization time] and because the whole assay could be performed within one working day, starting with wells pre-coated with DNA.

It was necessary to optimize the strength of SSC for a hybridization time of $2.5 \mathrm{~h}$. By hybridizing in $1 \times \mathrm{SSC}$ and stringent washing in $0.5 \times \mathrm{SSC}$, the DNA similarity was $15 \%$, too low for seven pairs of hybridizations compared with spectrophotometric values (data not shown). The use of $2 \times \mathrm{SSC}$ in both the hybridization and washing steps provided correspondence between DNA-DNA hybridization values obtained from the micro-well and spectrophotometric methods (see below).

Lower DNA similarity was obtained for DNA that was extracted to greater purity according to the protocol described by Angen et al. (1999) than by the present protocol (data not shown), indicating that variable quality of DNA preparations might affect the DNA similarities obtained. Dialysis of DNA samples overnight in $2 \times$ SSC did not change the DNA simi- 


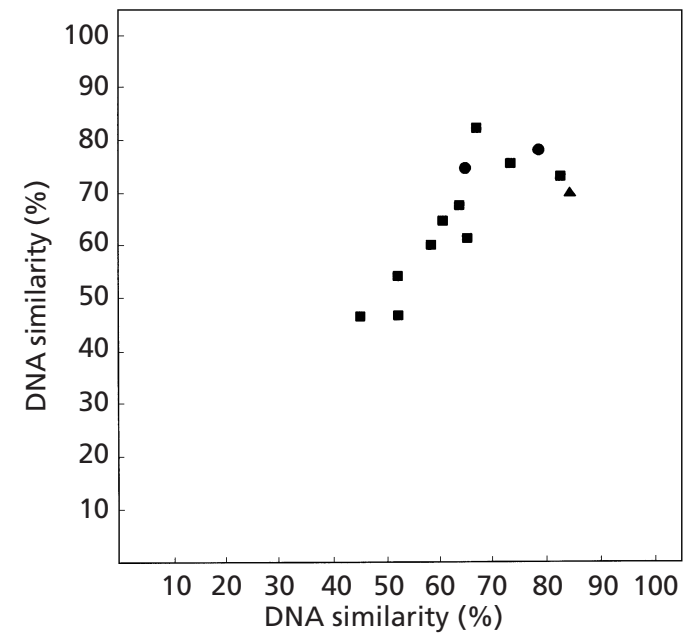

Fig. 2. Comparison of DNA similarity determined by interchange of the strains used for binding to micro-wells and addition in solution during hybridization with strains of Mannheimia species (O), avian [Pasteurella] haemolytica-like bacteria/' Actinobacillus salpingitidis' ( $\boldsymbol{\square})$ and Actinobacillus species $(\boldsymbol{\Delta})$. Each experiment included four replicates.

larities obtained by the micro-well method. Some organic compounds are known to increase the reassociation rate or to reduce the thermal stability of DNA hybrids (Johnson, 1991) and impurities in DNA preparations could act in a similar way.

\section{Comparison of DNA similarities determined by the spectrophotometric and micro-well methods}

In order for results obtained by the micro-well method to be acceptable, two criteria were applied. Fluorometric readings were only used for calculation of DNA similarities if the coefficient of variation did not exceed $15 \%$ for four wells. This led to the rejection of nine of a total of 94 experiments performed $(10 \%)$. The variation between fluorometric readings of individual micro-wells might be related to an additive effect of variation on binding, hybridization and detection steps, as well as to the many washing steps. The second criterion for acceptance of results was that no significant difference should be observed between DNA similarities calculated from two replications with the same pairs of strains, including interchange of the strains used for covalent binding and hybridization. This criterion led to the rejection of 19 of 85 experiments $(22 \%)$. The rejected experiments showed deviations of more than $3 \%$, but always less than $38 \%$ DNA similarity, from the mean of pairs of strains. For the accepted experiments (66 of 85), individual experiments never showed more than $11 \%$ deviation in DNA similarity from the mean. Some of the deviating results were related to the use of unlabelled DNA preparations with concentrations lower than $50 \mu \mathrm{g}$ $\mathrm{ml}^{-1}$ and samples of PAB-labelled DNA with less than $100 \mu \mathrm{g} \mathrm{ml} \mathrm{m}^{-1}$. For further use of the method, it is recommended that unlabelled and labelled DNA preparations of high concentration are used.

In at least two independent experiments, each including four repeats, the micro-well method was compared to the spectrophotometric method for 23 pairs of strains where DNA similarities ranged from 21 to $91 \%$, as determined by the spectrophotometric method. The correlation between DNA similarities obtained by interchange of strains used for covalent binding and hybridization was significant (Fig. 2, Table 2). Data for individual hybridization experiments are shown in Fig. 3. The mean deviation in DNA similarity between the two methods was only $3 \%$ when all data-pairs were compared; however, the linear relationship obtained between DNA similarities was poor (Table 2). The low slope of the regression line is related to significantly lower DNA similarities determined by the spectrophotometric compared with

Table 2. Statistical evaluation of DNA similarities determined by the micro-well method

The Pearson correlation coefficient was obtained between DNA similarities, derived by the microwell method, for pairs of strains when the strains used for covalent binding and hybridization were interchanged. Linear regression was performed for percentage DNA similarities determined by the micro-well method ( $y$, dependent variable) on similarities obtained by the spectrophotometric method ( $x$, independent variable).

\begin{tabular}{|lcc|}
\hline Data subset & Correlation (Pearson) & Regression \\
\hline $\begin{array}{l}\text { Experiments excluded that gave } \\
\text { significant differences from mean }\end{array}$ & $0 \cdot 794$ (significant; $P=0 \cdot 05)$ & $y=0 \cdot 534 x+30 \cdot 6, r^{2}=0 \cdot 327$ \\
DNA similarity & - & $y=0 \cdot 855 x+11 \cdot 0, r^{2}=0 \cdot 721$ \\
Experiments excluded that gave & & \\
significantly different mean & & \\
DNA similarities between & & \\
micro-well and & & \\
spectrophotometric methods & & \\
\hline
\end{tabular}




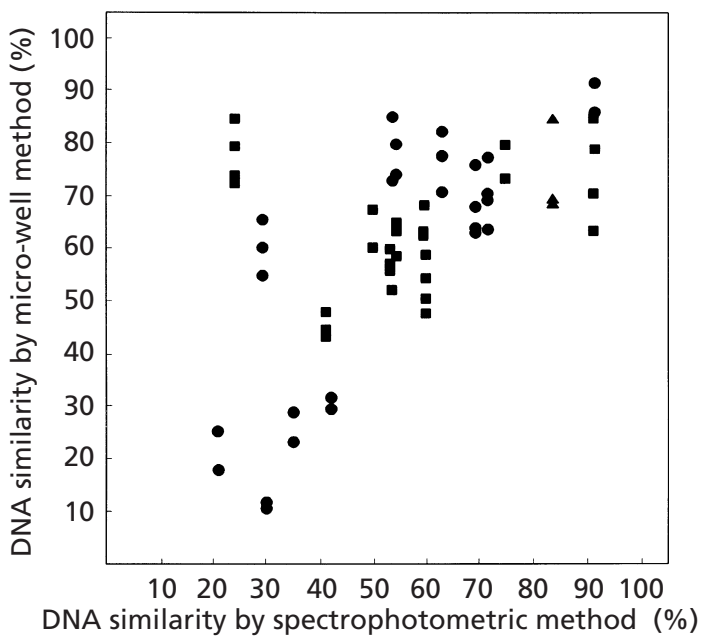

Fig. 3. Comparison between DNA similarities obtained by the micro-well and spectrophotometric methods for strains of Mannheimia species (@), avian [Pasteurella] haemolytica-like bacteria/' Actinobacillus salpingitidis' ( $\square$ ) and Actinobacillus species ( $\boldsymbol{\Delta})$. For the micro-well method, each experiment included four replicates. For the spectrophotometric method, data represent experiments performed with three replications.

the micro-well method for three pairs of hybridizations. If these data were removed, the relationship was improved tremendously (slope 0.855).

In five pairs of hybridizations (NCTC $9380^{\mathrm{T}}$, P 730; NCTC $9380^{\mathrm{T}}$, P 737; NCTC 9380 ${ }^{\mathrm{T}}$, UT 27; NCTC 9380 ${ }^{\mathrm{T}}$, HPA 121; CCM 5995, F 114), the DNA similarities obtained by the two methods were significantly different. We have reason to believe that the DNA-binding values obtained between NCTC $9380^{\mathrm{T}}$ and strains $\mathrm{P} 730$ and $\mathrm{P} 737$ by the spectrophotometric method, 29 and $54 \%$, respectively, are too low compared with the micro-well estimates of 60 and $78 \%$. Strains P 730, P 731, P 733, P 737, P 925 and UT 18 (Table 1) have been shown previously to represent the same species, Mannheimia glucosida (Angen et al., 1999). These strains were all closely linked to M. haemolytica by multilocus enzyme electrophoresis, 16S rRNA sequencing and DNA-DNA hybridization, and in the polyphasic taxonomic investigation performed, the DNA-binding values of strains P 730 and P 737 to NCTC $9380^{\mathrm{T}}$ were outliers. Both of these hybridizations were performed in the early 1980s (Mutters et al., 1986) and consequently the discrepancy might result from the use of different DNA preparations. By the micro-well method, all strains of M. glucosida have a DNA similarity to NCTC $9380^{\mathrm{T}}$ of between 64 and $79 \%$, a result which reflects the taxonomic relationship between these strains, as indicated by the polyphasic investigation (Angen et al., 1999).

For the avian [P.] haemolytica-like bacteria/ ${ }^{\prime} A$. salpingitidis' strains CCM 5995 and F 114, 16S rRNA gene sequence comparisons have shown $99 \cdot 2 \%$ simi- larity (unpublished result), indicating that the spectrophotometric DNA similarity value of only $24 \%$ was less likely than the micro-well estimate of $77 \%$. Similarities based on 16S rRNA sequence comparison are insufficient, per se, for species separation (Fox et al., 1992; Stackebrandt \& Goebel, 1994) and DNADNA hybridization must be repeated with these strains, both by the spectrophotometric and microwell methods, to solve this problem.

For strains UT 27 and HPA 121 hybridized with NCTC $9380^{\mathrm{T}}$, the estimates obtained by the micro-well method, of 31 and $11 \%$, respectively, underestimated the DNA similarities compared with the spectrophotometric estimates of 42 and $30 \%$. Lower correspondence between methods has been observed when strains were distantly related compared with bacteria belonging to the same hybridization group (Grimont et al., 1980). The major purpose of performing DNADNA hybridization experiments is to carry out classification at the species level, and low correspondence between methods for low DNA similarities $(<40 \%)$ seems to be a minor problem. For discrimination of groups related only at the genus level or higher, phylogenetic comparison of $16 \mathrm{~S}$ rRNA sequence is the primary method. In taxonomic studies, specific methods have to be used for specific taxonomic levels.

Divergence between DNA similarities obtained by different methods has been reported occasionally (Johnson et al., 1970; Bouvet \& Grimont, 1986). In most cases, good correspondence has been obtained, such as a mean variation of around $2 \%$ DNA similarity between the $\mathrm{S} 1$ nuclease and hydroxyapatite methods (Grimont et al., 1980) and between the spectrophotometric and hydroxyapatite methods (Kurtzman et al., 1980). The spectrophotometric method showed good correspondence to the filter method (variation around 3\% DNA similarity) (De Ley et al., 1970). The mean variation between the micro-well method and the spectrophotometric method fell in this low range.

The standard deviation of the DNA similarity determined by the micro-well method, of around $6 \%$, is comparable to other reports of the micro-well method (Goris et al., 1998) and the spectrophotometric method (Angen et al., 1999; Piechulla et al., 1985). However, lower mean standard deviations of only $2.4 \%$ for the spectrophotometric method have been reported (Huss et al., 1983). In the present study, linear regression of DNA similarities obtained by the micro-well method against data obtained by the spectrophotometric method showed a poor relationship. Exclusion of data that deviated between the two methods provides a relationship comparable to the study of Yaeshima et al. (1996), where the micro-well method showed good correspondence to the $\mathrm{S} 1$ nuclease method $(y=$ $0 \cdot 823 x+13 \cdot 93)$. In another study, the DNA similarities by the micro-well method were slightly higher than by the spectrophotometric method $(y=1 \cdot 05 x+2 \cdot 77)$ (Goris et al., 1998). 
The genotypic criteria for including taxa in the same species were set at $70 \%$ or greater DNA similarity and a difference in $T_{\mathrm{m}}$ of less than $5 \%$ (Wayne et al., 1987). A comparison of different taxonomic investigations showed this limit to vary from approximately 60 to $80 \%$ DNA similarity (Vandamme et al., 1996). For the strains of Mannheimia included in the present study, one strain was included in M. haemolytica with $91 \%$ similarity, whereas strains belonging to other species had $71 \%$ or lower similarity to the type strain of $M$. haemolytica on the basis of spectrophotometric data. The corresponding values were 89 and $78 \%$ using similarities obtained by the micro-well method. These limits are both in accordance with a species limit of around $85 \%$ for this genus (Angen et al., 1999; Mutters et al., 1989).

The same hybridization temperature of $65^{\circ} \mathrm{C}$ may be used for many other bacteria with DNA $\mathrm{G}+\mathrm{C}$ contents of around $40 \mathrm{~mol} \%$. Adjustment of the hybridization temperature would be necessary for bacteria deviating by $10 \mathrm{~mol} \%$ or more in their DNA $\mathrm{G}+\mathrm{C}$ content. The lowest limit would be for mycoplasmas, with $\mathrm{G}+\mathrm{C}$ contents as low as $25 \mathrm{~mol} \%$, giving an expected $T_{\mathrm{m}}$ of $85^{\circ} \mathrm{C}$ (Schildkraut \& Lifson, 1965) and a hybridization temperature of around $50{ }^{\circ} \mathrm{C}$ (Wetmur \& Davidson, 1968). The upper limit would be for high-G+C-content Gram-positives, with $\mathrm{G}+\mathrm{C}$ contents as high as $74 \mathrm{~mol} \%$, from which a predicted $T_{\mathrm{m}}$ of $105^{\circ} \mathrm{C}$ and a hybridization temperature of around $80^{\circ} \mathrm{C}$ can be calculated.

\section{Conclusion}

It is concluded that the present micro-well DNA-DNA hybridization method has reduced the time for analysis considerably, while the high levels of accuracy and precision of the existing methodology have been preserved. Due to savings of labour and time, it is now possible to perform full matrix hybridizations and thereby improve species definitions. Compared with the spectrophotometric method, only about $1 \%$ of the amount of DNA is needed when performing microwell hybridization. Correspondence to results obtained by the spectrophotometric method was obtained for a range of DNA similarities obtained by the micro-well method. In some instances, the data obtained by the micro-well method better reflected the taxonomic relationship between strains, as indicated by a polyphasic approach, than did those obtained by the spectrophotometric method.

In the application of the micro-well DNA-DNA hybridization method to other bacterial groups or using different DNA extraction protocols, the hybridization temperature might need adjustment. In addition, it is important to validate the results against the spectrophotometric method or another traditional DNA-DNA hybridization method until the performance of this new micro-well hybridization method is better known.

\section{ACKNOWLEDGEMENTS}

Gitte Frederiksen and Kirstina Holm provided excellent technical assistance for this study. The project was funded by the Danish Agricultural and Veterinary Research Council through grants 9600803 and 9702797.

\section{REFERENCES}

Adnan, S., Li, N., Miura, H., Hashimoto, Y., Yamamoto, H. \& Ezaki, T. (1993). Covalently immobilized DNA plate for luminometric DNA-DNA hybridization to identify viridans streptococci in under 2 hours. FEMS Microbiol Lett 106, 139-142.

Angen, Ø., Mutters, R., Caugant, D. A., Olsen, J. E. \& Bisgaard, M. (1999). Taxonomic relationships of the [Pasteurella] haemolytica complex as evaluated by DNA-DNA hybridizations and 16S rRNA sequencing with proposal of Mannheimia haemolytica gen. nov., comb. nov., Mannheimia granulomatis comb. nov., Mannheimia glucosida sp. nov., Mannheimia ruminalis sp. nov. and Mannheimia varigena sp. nov. Int J Syst Bacteriol 49, 67-86.

Bisgaard, M., Piechulla, K., Ying, Y.-T., Frederiksen, W. \& Mannheim, W. (1984). Prevalence of organisms described as Actinobacillus suis or haemolytic Actinobacillus equuli in the oral cavity of horses. Comparative investigations of strains obtained and porcine strains of $A$. suis sensu stricto. Acta Pathol Microbiol Immunol Scand Sect B 92, 291-298.

Bouvet, P. J. M. \& Grimont, P. A. D. (1986). Taxonomy of the genus Acinetobacter with the recognition of Acinetobacter baumannii sp. nov., Acinetobacter haemolyticus sp. nov., Acinetobacter johnsonii sp. nov., and Acinetobacter junii sp. nov. and emended descriptions of Acinetobacter calcoaceticus and Acinetobacter lwoffii. Int J Syst Bacteriol 36, 228-240.

Campbell, R. C. (1981). Statistics for Biologists, 2nd edn. Cambridge: Cambridge University Press.

Christensen, J. P. \& Bisgaard, M. (1997). Avian pasteurellosis: taxonomy of the organisms involved and aspects of pathogenesis. Avian Pathol 26, 461-483.

Chu, B. C. F., Wahl, G. M. \& Orgel, L. E. (1983). Derivatization of unprotected polynucleotides. Nucleic Acids Res 11, 6513-6529.

De Ley, J., Cattoir, H. \& Reynaerts, A. (1970). The quantitative measurement of DNA hybridization from renaturation rates. Eur J Biochem 12, 133-142.

Ezaki, T., Hashimoto, Y., Takeuchi, N., Yamamoto, H., Liu, S.-L., Miura, H., Matsui, K. \& Yabuuchi, E. (1988). Simple genetic method to identify viridans group streptococci by colorimetric dot hybridization and fluorometric hybridization in microdilution wells. J Clin Microbiol 26, 1708-1713.

Ezaki, T., Hashimoto, Y. \& Yabuuchi, E. (1989). Fluorometric deoxyribonucleic acid-deoxyribonucleic acid hybridization in microdilution wells as an alternative to membrane filter hybridization in which radioisotopes are used to determine genetic relatedness among bacterial strains. Int J Syst Bacteriol 39, 224-229.

Forster, A. C., McInnes, J. L., Skingle, D. C. \& Symons, R. H. (1985). Non-radioactive hybridization probes prepared by the chemical labelling of DNA and RNA with a novel reagent, photobiotin. Nucleic Acids Res 13, 745-761.

Fox, G. E., Wisotzkey, J. D. \& Jurtshuk, P., Jr (1992). How close is close: 16S rRNA sequence identity may not be sufficient to guarantee species identity. Int J Syst Bacteriol 42, 166-170.

Ghosh, S. S. \& Musso, G. F. (1987). Covalent attachment of oligonucleotides to solid supports. Nucleic Acids Res 15, $5353-5372$. 
Goris, J., Suzuki, K.-i., De Vos, P., Nakase, T. \& Kersters, K. (1998). Evaluation of a microplate DNA-DNA hybridization method compared with the initial renaturation method. Can J Microbiol 44, 1148-1153.

Grimont, P. A. D., Popoff, M. Y., Grimont, F., Coynault, C. \& Lemelin, M. (1980). Reproducibility and correlation study of three deoxyribonucleic acid hybridization procedures. Curr Microbiol 4, 325-330.

Huss, V. A. R., Festl, H. \& Schleifer, K. H. (1983). Studies on the spectrophotometric determination of DNA hybridization from renaturation rates. Syst Appl Microbiol 4, 184-192.

Johnson, J. L. (1981). Genetic characterization. In Manual of Methods for General Bacteriology, pp. 450-472. Edited by P. Gerhardt. Washington, DC: American Society for Microbiology.

Johnson, J. L. (1984). Nucleic acids in bacterial classification. In Bergey's Manual of Systematic Bacteriology, vol. 1, pp. 8-11. Edited by N. R. Krieg \& J. G. Holt. Baltimore: Williams \& Wilkins.

Johnson, J. L. (1991). DNA reassociation experiments. In Nucleic Acid Techniques in Bacterial Systematics, pp. 21-44. Edited by E. Stackebrandt \& M. Goodfellow. Chichester: Wiley.

Johnson, J. L., Anderson, R. S. \& Ordal, E. J. (1970). Nucleic acid homologies among oxidase-negative Moraxella species. $J$ Bacteriol 101, 568-573.

Kaznowski, A. (1995). A method of colorimetric DNA-DNA hybridisation in microplates with covalently immobilized DNA for identification of Aeromonas spp. Med Microbiol Lett 4, 362-369.

Kurtzman, C. P., Smiley, M. J., Johnson, C. J., Wickerham, L. J. \& Fuson, G. B. (1980). Two new and closely related heterothallic species, Pichia amylophila and Pichia mississippiensis: characterization by hybridization and deoxyribonucleic acid reassociation. Int J Syst Bacteriol 30, 208-216.

Marmur, J. (1961). A procedure for the isolation of deoxyribonucleic acid from micro-organisms. J Mol Biol 3, 208-218.

Murray, R. G. E., Brenner, D. J., Colwell, R. R., de Vos, P., Goodfellow, M., Grimont, P. A. D., Pfennig, N., Stackebrandt, E. \& Zavarzin, G. A. (1990). Report of the ad hoc committee on approaches to taxonomy within the Proteobacteria. Int $J$ Syst Bacteriol 40, 213-215.

Mutters, R., Bisgaard, M. \& Pohl, S. (1986). Taxonomic relationship of selected biogroups of Pasteurella haemolytica as revealed by DNA: DNA hybridizations. Acta Pathol Microbiol Immunol Scand Sect B 94, 195-202.

Mutters, R., Mannheim, W. \& Bisgaard, M. (1989). Taxonomy of the group. In Pasteurella and Pasteurellosis, pp. 3-34. Edited by C. Adlam \& J. M. Rutter. London: Academic Press.

Oroskar, A. A., Rasmussen, S. E., Rasmussen, H. N., Rasmussen, S. R., Sullivan, B. M. \& Johansson, A. (1996). Detection of immobilized amplicons by ELISA-like techniques. Clin Chem 42, 1547-1555.

Paul, J. H. \& Myers, B. (1982). Fluorometric determination of DNA in aquatic microorganisms by use of Hoechst 33258. Appl Environ Microbiol 43, 1393-1399.

Piechulla, K., Bisgaard, M., Gerlach, H. \& Mannheim, W. (1985). Taxonomy of some recently described avian Pasteurella/ Actinobacillus-like organisms as indicated by deoxyribonucleic acid relatedness. Avian Pathol 14, 281-311.

Rasmussen, S. R., Larsen, M. R. \& Rasmussen, S. E. (1991). Covalent immobilization of DNA onto polystyrene microwells: the molecules are only bound at the 5' end. Anal Biochem 198, $138-142$.

Schildkraut, C. \& Lifson, S. (1965). Dependence of the melting temperature of DNA on salt concentration. Biopolymers 3, 195-208.

Stackebrandt, E. \& Goebel, B. M. (1994). Taxonomic note: a place for DNA-DNA reassociation and 16S rRNA sequence analysis in the present species definition in bacteriology. Int $J$ Syst Bacteriol 44, 846-849.

Vandamme, P., Pot, B., Gillis, M., de Vos, P., Kersters, K. \& Swings, J. (1996). Polyphasic taxonomy, a consensus approach to bacterial systematics. Microbiol Rev 60, 407-438.

Wayne, L. G., Brenner, D. J., Colwell, R. R. \& 9 other authors (1987). Report of the ad hoc committee on reconciliation of approaches to bacterial systematics. Int J Syst Bacteriol 37, 463-464.

Wetmur, J. G. \& Davidson, N. (1968). Kinetics of renaturation of DNA. J Mol Biol 31, 349-370.

Wolf, S. F., Haines, L., Fisch, J., Kremsky, J. N., Dougherty, J. P. \& Jacobs, K. (1987). Rapid hybridization kinetics of DNA attached to submicron latex particles. Nucleic Acids Res 15, 2911-2926.

Yaeshima, T., Takahashi, S., Ishibashi, N. \& Shimamura, S. (1996). Identification of bifidobacteria from dairy products and evaluation of a microplate hybridization method. Int $J$ Food Microbiol 30, 303-313. 